\title{
Synthesis of Group IVB Metals Oxicarbides \\ by Carboreduction Reactions
}

\author{
A.D. Mazzoni ${ }^{\mathrm{a}}$, M.S. Conconi ${ }^{\mathrm{b}}$ \\ CETMIC (Centro de Tecnología de Recursos Minerales y Cerámica) \\ Cno. Centenario y 506. C.C. 49 (B1897ZCA) M.B.Gonnet - Buenos Aires, Argentina \\ ${ }^{a}$ CONICET y UNLP \\ ${ }^{\mathrm{b}} \mathrm{CICPBA}$
}

Received: December 21, 2001; Revised: July 30, 2002

The metals of the group IV B (Ti, Zr, Hf) present a series of carbides and oxicarbides with scientific and technological interest. Many of these compounds belong to the subsystem "MO - MC" of the pseudoternary "MO - MN - MC" system (where M = Ti, Zr or Hf).

In this work carboreduction reactions of $\mathrm{TiO}_{2}$ and $\mathrm{ZrO}_{2}$ were performed in argon atmosphere, using temperatures from $1250^{\circ}$ to $1650^{\circ}$ and reaction times of $120 \mathrm{~min}$. The oxicarbides obtained were in the range $\mathrm{TiC}_{0.16} \mathrm{O}_{0.84}$ to $\mathrm{TiC}_{0.73} \mathrm{O}_{0.27}$ and $\mathrm{ZrC}_{0.46} \mathrm{O}_{0.54}$ to $\mathrm{ZrC}_{0.90} \mathrm{O}_{0.10}$ respectively.

The reaction products were characterized by X-ray diffraction (XRD), with the calculation of their cell constants by means of the Rietveld method. Scanning Electron Microscopy (SEM) was used in the characterization of powdered materials. Additionally, the carborreduction reaction was followed by weight loss.

Keywords: carboreduction, anatase, badeleyite, oxicarbides, carbides

\section{Introduction}

The group IV B metals, as titanium (Ti) and zirconium $(\mathrm{Zr})$, present pseudoternary systems of the type "MO - MN - MC" (where M = metal). Both systems show substitutional solid solutions which correspond to extensive monophasic zones. The solutions, named $\mathrm{M}(\mathrm{C}, \mathrm{N}, \mathrm{O})$, have the same cubic crystalline structure (S.G.:Fm $3 \mathrm{~m}$ ) that $\mathrm{MN}, \mathrm{MC}$ and $\mathrm{MO}$ phases in the corners of diagrams. The unit-cell parameter $\left(\mathrm{a}_{\mathrm{o}}\right)$ of $\mathrm{M}(\mathrm{C}, \mathrm{N}, \mathrm{O})$ phase depends on the $\mathrm{MC}, \mathrm{MO}$ and $\mathrm{MN}$ content.

Figure 1 shows the pseudoternary phase diagram "TiOTiN-TiC" proposed by Neumann et al. ${ }^{1}$. The monophasic zone covers the whole diagram at temperatures higher than $1100{ }^{\circ} \mathrm{C}$. This zone corresponds to the $\operatorname{Ti}(\mathrm{C}, \mathrm{N}, \mathrm{O})$ phase. The cell parameter $\mathrm{a}_{\mathrm{o}}$ varies between $4.12 \AA$ and $4.32 \AA^{1}$.

The pseudoternary system " $\mathrm{ZrO}-\mathrm{ZrN}-\mathrm{ZrC}$ " was studied by Constant $e t a l{ }^{2}$. These authors observed a considerable solubility of " $\mathrm{ZrO}$ " (added as an equimolar mix of $\mathrm{ZrO}_{2}$ $+\mathrm{Zr})$ in $\mathrm{ZrC}, \mathrm{ZrN}$ and $\mathrm{Zr}(\mathrm{C}, \mathrm{N})$. Figure 2 shows the limit of monophasic zone at $1600{ }^{\circ} \mathrm{C}$. The $\mathrm{a}_{\mathrm{o}}$ parameter of the phase $\mathrm{Zr}(\mathrm{C}, \mathrm{O}, \mathrm{N})$ changes between $4.570 \AA$ and $4.692 \AA$.

The monophasic zones cover in part the MO-MC axes in both systems. Thus, the subsystems "MO-MC" present oxycarbides $\mathrm{M}(\mathrm{C}, \mathrm{O})$. These oxycarbides, $\mathrm{Ti}(\mathrm{C}, \mathrm{O})$ and $\operatorname{Zr}(\mathrm{C}, \mathrm{O})$, have the same cubic structure of $\mathrm{M}(\mathrm{C}, \mathrm{N}, \mathrm{O})$ with $\mathrm{a}_{\mathrm{o}}$ depending on MC and MO content. The values of $\mathrm{a}_{\mathrm{o}}$ increase with the MC content, the highest value corresponds to $\mathrm{MC}$ pure phase.

The synthesis of these compounds is usually obtained by $\mathrm{TiO}, \mathrm{TiC}$ or $\mathrm{ZrO}_{2} \mathrm{Zr}, \mathrm{ZrC}$ reactions in argon atmosphere or vacuum ${ }^{3,4}$. Carborreduction reactions of the $\mathrm{MO}_{2}$ $\left(\mathrm{TiO}_{2}\right.$-anatasa, $\mathrm{ZrO}_{2}$ - badeleyite) oxides constitute an alternative method to obtain these phases. This method is within the present tendency to use abundant and cheap raw materials to obtain ceramic powders (oxides as well as carbides). Ceramics are manufactured starting from well characterized raw materials and then purified in order to control the degree of impurities.

The Rietveld method allows to properly characterize

*e-mail: mazzoni@netverk.com.ar 


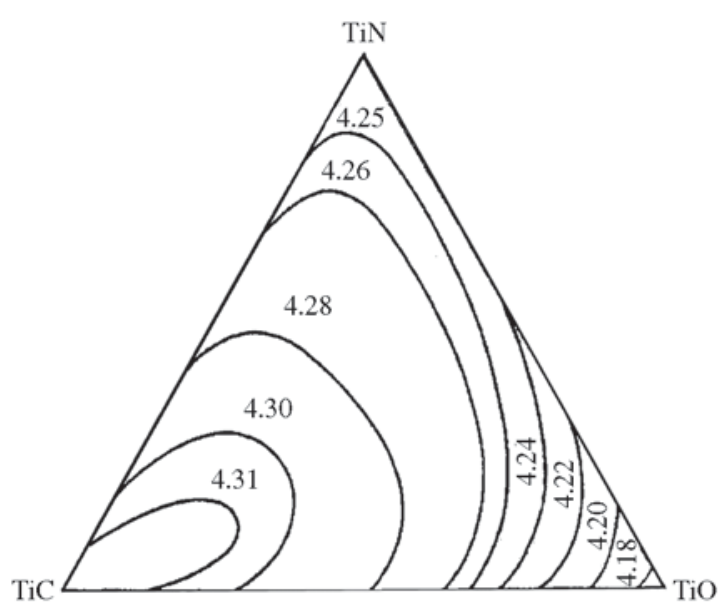

Figure 1. Pseudoternary diagram of the TiN-TiC-TiO system at $1100{ }^{\circ} \mathrm{C}$ (from Neumann et al. $)^{1}$. The cell parameters $\mathrm{a}_{\mathrm{o}}$ of $\mathrm{Ti}(\mathrm{C}, \mathrm{N}, \mathrm{O})$ are indicated. The lines separate zones of similar $\mathrm{a}_{\mathrm{o}}$.

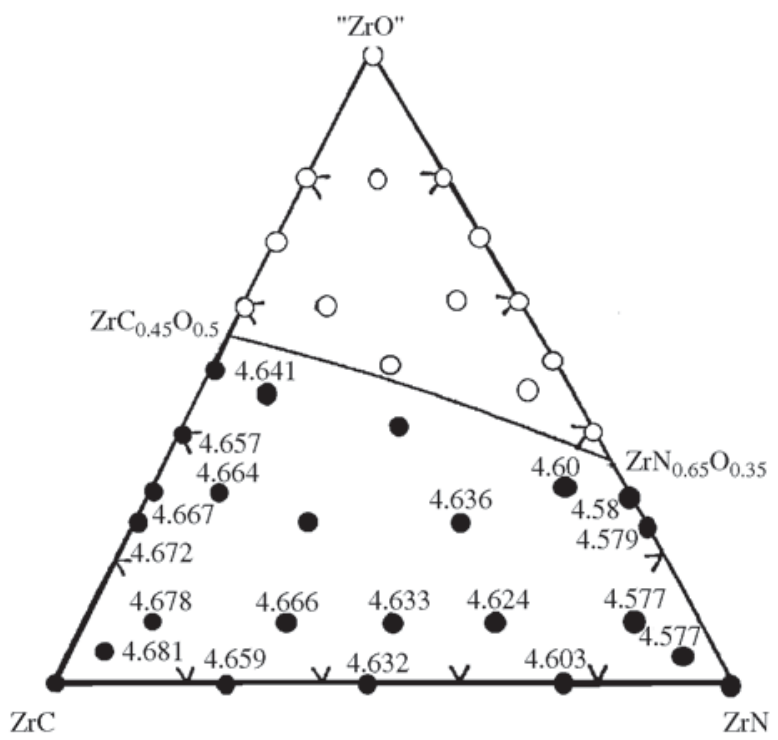

Figure 2. Pseudoternary diagram of the $\mathrm{ZrN}-\mathrm{ZrO}-\mathrm{ZrC}$ system at $1600{ }^{\circ} \mathrm{C}$ (from Constant et al. $)^{2}$. The unit-cell parameters $\mathrm{a}_{\mathrm{o}}$ of $\mathrm{Zr}(\mathrm{C}, \mathrm{N}, \mathrm{O})$ are indicated $\bullet$ monophase zone and o polyphase zone.

crystalline phases by x-ray diffraction (XRD). This method was developed by Hugo Rietveld in $1969^{5}$, in order to refine crystalline structures using neutron diffraction data. At the present time, it is also used to perform analysis of structure and crystalline defects, reticular parameter measurement and quantitative analysis in X-ray diffraction.

In this work, the carborreduction reactions of anatasa and badeleyite were studied by XRD. Reaction products were characterized by XRD (Rietveld) and scanning electron microscopy (SEM). The weight loss was also measured.

\section{Materials And Methods}

Raw materials used were badeleyite Riedel-de Haën from Germany with more than $99 \%\left(\mathrm{ZrO}_{2}+\mathrm{HfO}_{2}\right)$ content, anatase Fluka from Switzerland with more than $99 \% \mathrm{TiO}_{2}$ content and carbon black (carbon 97\%, ash 1\%, volatiles $2 \%$ and a specific surface area BET $=45 \mathrm{~m}^{2} / \mathrm{g}$ ). All powders have an average particle size lower than $5 \mathrm{~mm}$. The argon used contains less than $5 \mathrm{ppm}$ of $\mathrm{O}_{2}$ and $\mathrm{H}_{2} \mathrm{O}$.

Samples were prepared by wet mixing of the calculated amounts of regents, and then they were dried and pressed at $39 \mathrm{MPa}$ into cylinders of $2 \mathrm{~mm}$ in height and $10 \mathrm{~mm}$ in diameter. Samples were called by a letter and the $\mathrm{C} / \mathrm{MO}_{2}$ relation. Letter A was used for samples prepared from anatase and letter B for samples from badeleyite. Thus, we obtain the samples A200 $\left(\mathrm{C} / \mathrm{TiO}_{2}=0.200\right), \mathrm{A} 280, \mathrm{~A} 360$, $\mathrm{A} 430$ and $\mathrm{A} 500$ and the samples $\mathrm{B} 180\left(\mathrm{C} / \mathrm{ZrO}_{2}=0.180\right)$, B210, B240, B300 and B450.

Reactions were performed in a horizontal alumina reactor with argon flowing through it. The pressure used was $0.05 \mathrm{Mpa}$ above the atmospheric pressure, and the flow was $1 \mathrm{l} / \mathrm{min}$. Experiments were carried out within the range of 1250 to $1650{ }^{\circ} \mathrm{C}$ with reaction times of $120 \mathrm{~min}$ and the temperature slopes were $10^{\circ} \mathrm{C} / \mathrm{min}$ upward as well as downward. The Ar flow was kept during cooling up to $200^{\circ} \mathrm{C}$.

Crystalline phases were characterized by X-ray diffraction with a Philips 3020 Goniometer with a PW 3710 controller, $\mathrm{Cu}-\mathrm{K} \alpha$, Ni filter, $40 \mathrm{kV}-20 \mathrm{~mA}$. The scanning was made between $10^{\circ}$ and $75^{\circ}$ with step size of $0.02^{\circ}$ and a step counting time of $2 \mathrm{sec}$. Some samples were scanned with $40 \mathrm{kV}-30 \mathrm{~mA}$ and a step counting time of $4 \mathrm{sec}$. The set of divergence, receiving and scattering slits were $1^{\circ}, 0.2^{\circ}$, $1^{\circ}$ and no monochromator was used. The unit cell parameters were refined using the Rietveld refinement FULLPROF ${ }^{6}$ program. The starting crystallographic data for each phase were taken from literature ${ }^{7-11}$. The refining sequence began with the adjustment of the shift in $2 \theta$ due to vertical sample displacement and the background. To do this, elemental Si was added to the samples as internal standard. Then, for each phase, the scale factors, the cell constants, the parameters for calculation of the full-width-athalf-maximum (FWHM), the profile (pseudo Voight) function coefficients, the preferred orientation parameter for the March function, were sequentially refined. Quantitative phase analysis was also performed by FULLPROF program based on the scale factors of each phase.

The $\operatorname{Zr}(\mathrm{C}, \mathrm{O})$ and $\operatorname{Ti}(\mathrm{C}, \mathrm{O})$ crystallite sizes were determined by the full-width-at-half-maximum of peak (200) for 
obtained after refinement, using the Scherrer equation and the PC-APD (PW 1877) Analytical Powder Diffraction Software, Version 3.6. Weight losses were measured by weighing the samples before and after the reaction process.

The reaction products were also studied by scanning electron microscopy (SEM) using a Philips 505 equipment.

\section{Results And Discussion}

The following theoretical equations describe the reactions carried out in these systems:

$$
\begin{aligned}
& \mathrm{TiO}_{2}+(\mathrm{a}+\mathrm{b}) \mathrm{C} \rightarrow\left\{\mathrm{TiC}_{\mathrm{a}} \mathrm{O}_{2-\mathrm{b}}\right\}+\mathrm{b} \mathrm{CO} \\
& \mathrm{ZrO}_{2}+(\mathrm{c}+\mathrm{d}) \mathrm{C} \rightarrow\left\{\mathrm{ZrC}_{\mathrm{c}} \mathrm{O}_{2-\mathrm{d}}\right\}+\mathrm{d} \mathrm{CO}
\end{aligned}
$$

where $\mathrm{a}, \mathrm{b}, \mathrm{c}$ and $\mathrm{d}$ are stoichiometric coefficients $(0 \leq \mathrm{a} \leq 1$,
$1 \leq \mathrm{b} \leq 2,0.40 \leq \mathrm{c} \leq 1$ and $1.4 \leq \mathrm{d} \leq 2)$. The phases $\left\{\mathrm{TiC}_{\mathrm{a}} \mathrm{O}_{2-\mathrm{b}}\right\}$ and $\left\{\mathrm{ZrC}_{\mathrm{c}} \mathrm{O}_{2-\mathrm{d}}\right\}$ are metal oxicarbides belonging to the MC-MO edge of the MC-MO-MN system. These phases are called $\mathrm{Ti}(\mathrm{C}, \mathrm{O})$ and $\mathrm{Zr}(\mathrm{C}, \mathrm{O})$ respectively.

Table 1 shows the results obtained in the $\mathrm{TiO}_{2}$ carborreduction. Estimated standard deviations of weight percents were derived from the estimated standard deviations on individual scale factors for the respective phases, and other error contributions were not included.

The Ti $(\mathrm{C}, \mathrm{O})$ content increase with the temperature and carbon content being the unique product obtained at high temperatures and high $\mathrm{C}$ content.

Table 2 shows the values of $a_{0}$ obtained by the Rietveld method for the $\mathrm{Ti}(\mathrm{C}, \mathrm{O})$ phases. Ranges of values appear in some cases due to the necessity of using two or more $\mathrm{Ti}(\mathrm{C}, \mathrm{O})$

\begin{tabular}{|c|c|c|c|c|c|}
\hline $\begin{array}{l}\text { Sample/ } \\
\text { Temperature }\end{array}$ & $1250^{\circ} \mathrm{C}$ & $1350{ }^{\circ} \mathrm{C}$ & $1450^{\circ} \mathrm{C}$ & $1550{ }^{\circ} \mathrm{C}$ & $1650^{\circ} \mathrm{C}$ \\
\hline A500 & $\begin{array}{cc}\mathrm{Ti}(\mathrm{C}, \mathrm{O}) & 95.4(7)^{*} \\
\mathrm{Ti}_{3} \mathrm{O}_{5} & 4.6(8)\end{array}$ & $\mathrm{Ti}(\mathrm{C}, \mathrm{O}) 100$ & $\operatorname{Ti}(\mathrm{C}, \mathrm{O}) 100$ & $\operatorname{Ti}(C, O) 100$ & $\operatorname{Ti}(\mathrm{C}, \mathrm{O}) 100$ \\
\hline A430 & $\begin{array}{c}\mathrm{Ti}(\mathrm{C}, \mathrm{O}) 90.3(6) \\
\mathrm{Ti}_{3} \mathrm{O}_{5} 9.7(8)\end{array}$ & $\begin{array}{c}\mathrm{Ti}(\mathrm{C}, \mathrm{O}) \text { 95.5(7) } \\
\gamma \mathrm{Ti}_{3} \mathrm{O}_{5} 4.5(6)\end{array}$ & $\operatorname{Ti}(\mathrm{C}, \mathrm{O}) 100$ & $\operatorname{Ti}(\mathrm{C}, \mathrm{O}) 100$ & $\operatorname{Ti}(C, O) 100$ \\
\hline A360 & $\begin{array}{c}\mathrm{Ti}(\mathrm{C}, \mathrm{O}) 77.7(6) \\
\mathrm{Ti}_{3} \mathrm{O}_{5} 22.3(4)\end{array}$ & $\begin{array}{c}\mathrm{Ti}(\mathrm{C}, \mathrm{O}) 89.9(6) \\
\gamma \mathrm{Ti}_{3} \mathrm{O}_{5} 6.9(5) \\
\mathrm{Ti}_{5} \mathrm{O}_{9} 3.9(7)\end{array}$ & $\operatorname{Ti}(\mathrm{C}, \mathrm{O}) 100$ & $\operatorname{Ti}(\mathrm{C}, \mathrm{O}) 100$ & $\operatorname{Ti}(\mathrm{C}, \mathrm{O}) 100$ \\
\hline A 280 & $\begin{array}{c}\mathrm{Ti}(\mathrm{C}, \mathrm{O}) 71.1(6) \\
\mathrm{Ti}_{3} \mathrm{O}_{5} 28.9(5)\end{array}$ & $\begin{array}{c}\mathrm{Ti}(\mathrm{C}, \mathrm{O}) 69.9(3) \\
\gamma \mathrm{Ti}_{3} \mathrm{O}_{5} 2.4(5) \\
\mathrm{Ti}_{2} \mathrm{O}_{3} 22.9(4) \\
\mathrm{Ti}_{5} \mathrm{O}_{9} 4.8(6)\end{array}$ & $\begin{array}{c}\mathrm{Ti}(\mathrm{C}, \mathrm{O}) 70.0(6) \\
\gamma \mathrm{Ti}_{3} \mathrm{O}_{5} 6.2(5) \\
\mathrm{Ti}_{2} \mathrm{O}_{3} 16.2(4) \\
\mathrm{Ti}_{5} \mathrm{O}_{9} 7.5(4)\end{array}$ & $\begin{array}{c}\mathrm{Ti}(\mathrm{C}, \mathrm{O}) 88.8(4) \\
\mathrm{Ti}_{2} \mathrm{O}_{3} 11.2(8)\end{array}$ & $\begin{array}{r}\mathrm{Ti}(\mathrm{C}, \mathrm{O}) 95.6(7) \\
\gamma \mathrm{Ti}_{3} \mathrm{O}_{5} 1.5(9) \\
\mathrm{Ti}_{2} \mathrm{O}_{3} 1.5(9) \\
\mathrm{Ti}_{5} \mathrm{O}_{9} 1.5(8)\end{array}$ \\
\hline A200 & $\begin{array}{c}\mathrm{Ti}(\mathrm{C}, \mathrm{O}) 52.6(5) \\
\mathrm{Ti}_{3} \mathrm{O}_{5} 47.4(4)\end{array}$ & $\begin{array}{c}\mathrm{Ti}(\mathrm{C}, \mathrm{O}) 41.9(4) \\
\gamma \mathrm{Ti}_{3} \mathrm{O}_{5} 22.1(6) \\
\mathrm{Ti}_{2} \mathrm{O}_{3} 29.1(5) \\
\mathrm{Ti}_{5} \mathrm{O}_{9} 6.9(8)\end{array}$ & $\begin{array}{c}\mathrm{Ti}(\mathrm{C}, \mathrm{O}) 41.0(7) \\
\gamma \mathrm{Ti}_{3} \mathrm{O}_{5} 5.2(5) \\
\mathrm{Ti}_{2} \mathrm{O}_{3} 50.1(5) \\
\mathrm{Ti}_{5} \mathrm{O}_{9} 3.7(8)\end{array}$ & $\begin{array}{c}\mathrm{Ti}(\mathrm{C}, \mathrm{O}) 45.7(6) \\
\mathrm{Ti}_{2} \mathrm{O}_{3} 54.3(7)\end{array}$ & $\begin{array}{rr}\mathrm{Ti}(\mathrm{C}, \mathrm{O}) & 74.4(8) \\
\gamma \mathrm{Ti}_{3} \mathrm{O}_{5} & 5.1(3) \\
\mathrm{Ti}_{2} \mathrm{O}_{3} & 14.7(6) \\
\mathrm{Ti}_{5} \mathrm{O}_{9} & 5.8(7)\end{array}$ \\
\hline
\end{tabular}

Table 1. Phases content (wt.\%) of $\mathrm{TiO}_{2}$ samples at different temperatures.

* Values in parenthesis represent estimated standard deviations in the last quoted place.

Table 2. Refined unit cell parameter $\mathrm{a}_{\mathrm{o}}(\AA)$ for $\mathrm{Ti}(\mathrm{C}, \mathrm{O})$ phase in $\mathrm{TiO}_{2}$ samples at different temperatures.

\begin{tabular}{lccccc}
\hline $\begin{array}{l}\text { Sample/ } \\
\text { Temperature }\end{array}$ & $1250{ }^{\circ} \mathrm{C}$ & $1350{ }^{\circ} \mathrm{C}$ & $1450{ }^{\circ} \mathrm{C}$ & $1550{ }^{\circ} \mathrm{C}$ & $1650{ }^{\circ} \mathrm{C}$ \\
\hline A500 & {$[4.261-4.281]$} & {$[4.292]$} & {$[4.294-4.308]$} & {$[4.301-4.308]$} & {$[4.304]$} \\
A430 & {$[4.275-4.287]$} & {$[4.283-4.296]$} & {$[4.289-4.304]$} & {$[4.301-4.308]$} & {$[4.290-4.304]$} \\
A360 & {$[4.262-4.287]$} & {$[4.275-4.293]$} & {$[4.263-4.293]$} & {$[4.285-4.302]$} & {$[4.277-4.297]$} \\
A280 & {$[4.266-4.288]$} & {$[4.276-4.293]$} & {$[4.265-4.290]$} & {$[4.267-4.296]$} & {$[4.277-4.297]$} \\
A200 & {$[4.271-4.286]$} & {$[4.274-4.293]$} & {$[4.266-4.288]$} & {$[4.259-4.276]$} & {$[4.235-4.255]$} \\
\hline
\end{tabular}


(a)
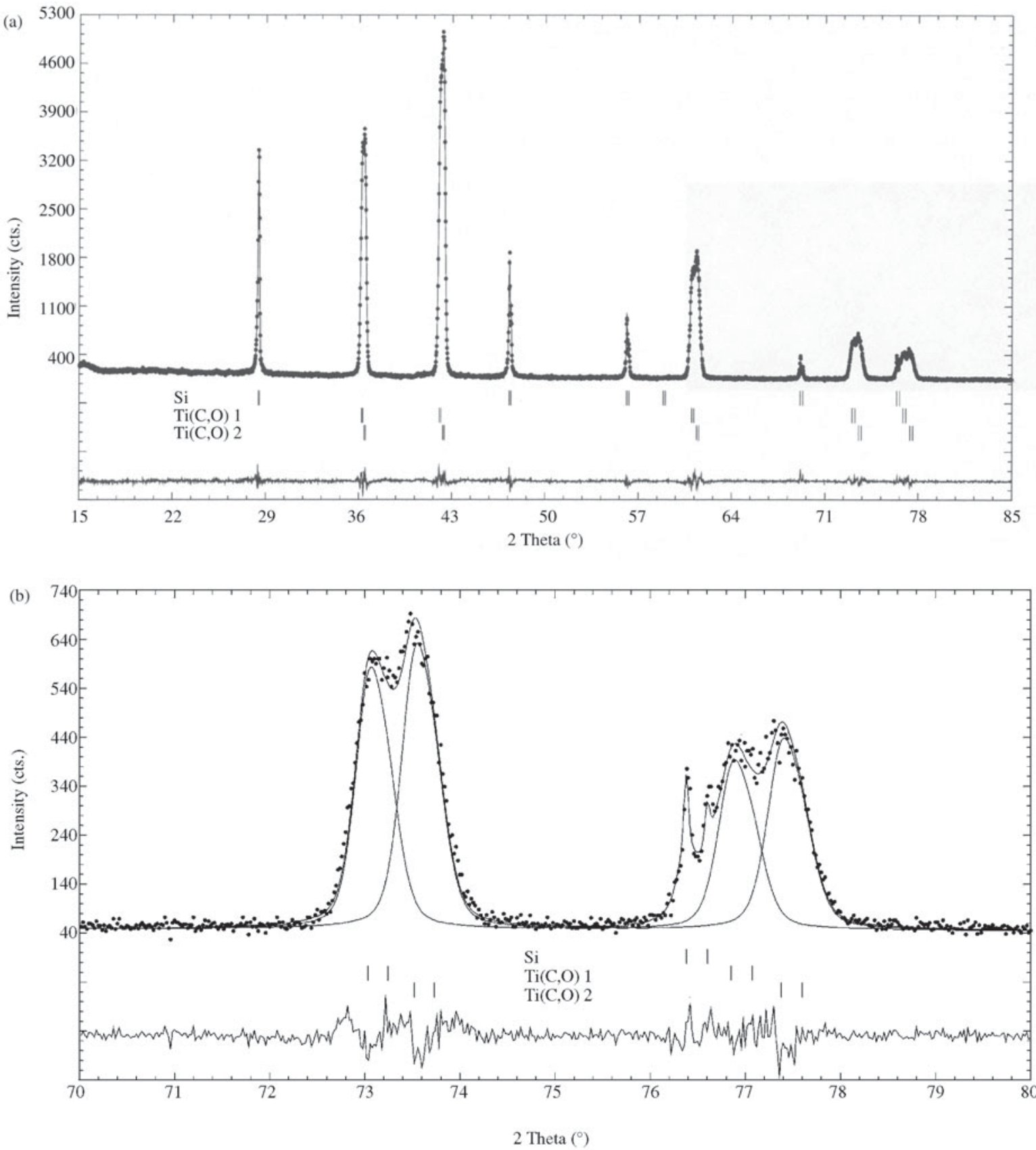

Figure 3. a) Final Rietveld plot for sample A360 treated at $1450{ }^{\circ} \mathrm{C}$. b) Amplified plot of $70^{\circ}-80^{\circ}$ zone.

phases in order to obtain a good fitting of peak widths. Figure $3 \mathrm{a}$ shows the final Rietveld plot for sample A360 treated at 1450 and Fig. $3 \mathrm{~b}$ is part of the same graphic amplified to show the overlap of $\mathrm{Ti}(\mathrm{C}, \mathrm{O})$ peaks belonging to different phases. In Fig. 3b, individual calculated profiles for both $\mathrm{Ti}(\mathrm{C}, \mathrm{O})$ phases are also shown.

Within the temperature range used in these experiments, the $\mathrm{Ti}(\mathrm{C}, \mathrm{O})$ cubic phase is throughout the $\mathrm{TiO}-\mathrm{TiC}$ axis (Fig. 4) as well as the Ti (C, N, O) cubic phases cover the triangular diagram completely (Fig. 1). The carbon content of samples A would allow to obtain the complete composition range (100\% $\mathrm{TiO}$ to $100 \% \mathrm{TiC})$. In Table 2 , a values of $\mathrm{Ti}(\mathrm{C}, \mathrm{O})$ are between $4.234 \AA$ and $4.308 \AA$. These values correspond to a composition range between $\mathrm{TiC}_{0.16} \mathrm{O}_{0.84}$ and 
Table 3. Mean unit-cell parameters of titanium oxides obtained in the refinement

\begin{tabular}{lccccccc}
\hline Phase & $\mathrm{a}$ & $\mathrm{b}$ & $\mathrm{c}$ & $\alpha$ & $\beta$ & $\gamma$ & Space Group \\
\hline $\mathrm{Ti}_{2} \mathrm{O}_{3}$ & $5.133(9)$ & $5.133(9)$ & $13.710(8)$ & & & & $\mathrm{R}-3 \mathrm{C}$ \\
$\mathrm{Ti}_{3} \mathrm{O}_{5}$ & $9.815(10)$ & $3.788(10)$ & $9.892(11)$ & & $91.50(3)$ & & $\mathrm{C} 2 / \mathrm{m}$ \\
$\gamma-\mathrm{Ti}_{3} \mathrm{O}_{5}$ & $9.967(8)$ & $5.075(9)$ & $7.176(9)$ & & $109.10(9)$ & & $\mathrm{I} 2 / \mathrm{a}$ \\
$\mathrm{Ti}_{5} \mathrm{O}_{9}$ & $5.589(7)$ & $7.135(8)$ & $8.862(6)$ & $97.28(9)$ & $112.73(8)$ & $108.76(9)$ & $\mathrm{P} 1$ \\
\hline
\end{tabular}

Table 4. Weight loss $\%$ in $\mathrm{TiO}_{2}$ samples at different temperatures.

\begin{tabular}{lccccc}
\hline Sample/ & $1250{ }^{\circ} \mathrm{C}$ & $1350^{\circ} \mathrm{C}$ & $1450{ }^{\circ} \mathrm{C}$ & $1550{ }^{\circ} \mathrm{C}$ & $1650^{\circ} \mathrm{C}$ \\
Temperature & & & & & \\
\hline A500 & 42 & 45 & 45 & 49 & 48 \\
A430 & 41 & 45 & 46 & 46 & 46 \\
A360 & 37 & 38 & 38 & 42 & 42 \\
A280 & 31 & 32 & 35 & 36 & 37 \\
A200 & 25 & 28 & 27 & 36 & 29 \\
\hline
\end{tabular}

Table 5. Unit-cell parameter $\mathrm{a}_{\mathrm{o}}$ and weight $\%$ of $\mathrm{Zr}(\mathrm{C}, \mathrm{O})$ for $\mathrm{ZrO}_{2}$ samples.

\begin{tabular}{lccccc}
\hline $\begin{array}{l}\text { Sample/ } \\
\text { Temperature }\end{array}$ & $1400{ }^{\circ} \mathrm{C}$ & $1460{ }^{\circ} \mathrm{C}$ & $1500{ }^{\circ} \mathrm{C}$ & $1600{ }^{\circ} \mathrm{C}$ & $1650{ }^{\circ} \mathrm{C}$ \\
\hline B450 & {$[4.643-4.650]$} & {$[4.658-4.660]$} & {$[4.681]$} & {$[4.657-4.672]$} & {$[4.682]$} \\
& $12.9(7)^{*}$ & $16.5(6)$ & $34.6(6)$ & $87.2(6)$ & 100 \\
B300 & {$[4.646-4.658]$} & {$[4.666]$} & {$[4.679]$} & {$[4.654-, 4.667]$} & {$[4.678]$} \\
& $8.7(6)$ & $13.8(7)$ & $30.2(6)$ & $66.7(8)$ & $81.8(6)$ \\
B240 & {$[4.643-4.661]$} & {$[4.658-4.667]$} & {$[4.682]$} & {$[4.655-4.668]$} & {$[4.678]$} \\
& $9.8(7)$ & $17.6(5)$ & $31.5(5)$ & $64.2(5)$ & $66.0(5)$ \\
B210 & {$[4.640-, 4.663]$} & {$[4.650-4.663]$} & {$[4.681]$} & {$[4.651-4.669]$} & {$[4.677]$} \\
& $6.5(6)$ & $16.3(5)$ & $30.5(8)$ & $55.2(3)$ & $63.2(7)$ \\
B180 & {$[4.650-4.669]$} & {$[4.659-4.670]$} & {$[4.683]$} & {$[4.648-4.659]$} & {$[4.672]$} \\
& $7.3(8)$ & $19.9(7)$ & $33.0(4)$ & $56.8(6)$ & $56.6(4)$ \\
\hline
\end{tabular}

Note: Values between brackets are unit-cell parameters in $\AA$.

* Values in parenthesis represent estimated standard deviations in the last quoted place for wt.\% data.

Table 6. Weight loss $\%$ in $\mathrm{ZrO}_{2}$ samples at different temperatures.

\begin{tabular}{lccccc}
\hline $\begin{array}{l}\text { Sample/ } \\
\text { Temperature }\end{array}$ & $1400{ }^{\circ} \mathrm{C}$ & $1460{ }^{\circ} \mathrm{C}$ & $1500{ }^{\circ} \mathrm{C}$ & $1600{ }^{\circ} \mathrm{C}$ & $1650{ }^{\circ} \mathrm{C}$ \\
\hline B450 & $\sim 13$ & 13 & 17 & 30 & 37 \\
B300 & 9 & 12 & 15 & 30 & 31 \\
B240 & 8 & 12 & 16 & 18 & 27 \\
B210 & 9 & 12 & 16 & 20 & 24 \\
B180 & 10 & 17 & 17 & 24 & 26 \\
\hline
\end{tabular}

$\mathrm{TiC}_{0.73} \mathrm{O}_{0.27}$ (between 16 and $73 \mathrm{~mol} \%$ of $\mathrm{TiC}$ ). The composition range was determined using the calibration curve $\mathrm{a}_{\mathrm{o}}$ vs. composition of $\mathrm{Ti}(\mathrm{C}, \mathrm{O})$ (Fig. 4). This curve, from Neuman et al. ${ }^{1}$, was determined from samples prepared by reaction of pure $\mathrm{TiO}$ and $\mathrm{TiC}$.

The values of $a_{0}$ tend to be higher with the increase of reaction temperature. It is not possible to determine a defined tendency of $\mathrm{a}_{\mathrm{o}}$ values changes with carbon content. This little $a_{0}$ variation is due to the low slope in Fig. 4 where big changes in composition produce little shift of the unit cell parameter.

Some titanium sub-oxides were also detected. These 


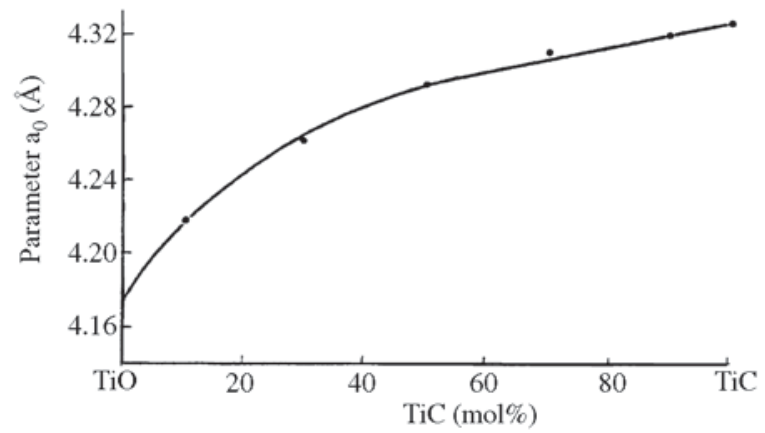

Figure 4. Unit-cell parameter $\mathrm{a}_{\mathrm{o}} v s$. Ti(C,O) composition taken from Neumann et al. ${ }^{1}$. phases are $\mathrm{Ti}_{3} \mathrm{O}_{5}, \gamma-\mathrm{Ti}_{3} \mathrm{O}_{5}, \mathrm{Ti}_{2} \mathrm{O}_{3}$, and Magnéli phases $\left(\mathrm{Ti}_{\mathrm{n}} \mathrm{O}_{\mathrm{n}+2}\right)$ similar to those observed by other authors ${ }^{12}$. These oxides become more important at low temperature and in samples with low carbon content. In Table 3 the refined unit-cell parameters of these phases are in good agreement with published data ${ }^{8-11}$.

The weight losses showed in Table 4 allow us to see that the reaction progresses with the increase of carbon content and temperature, being the obtained tendency consistent with the detected crystalline phases, within the margin of experimental error.

Badeleyite carborreduction results (reaction B) for the 5 studied samples are shown in Tables 5 and 6.
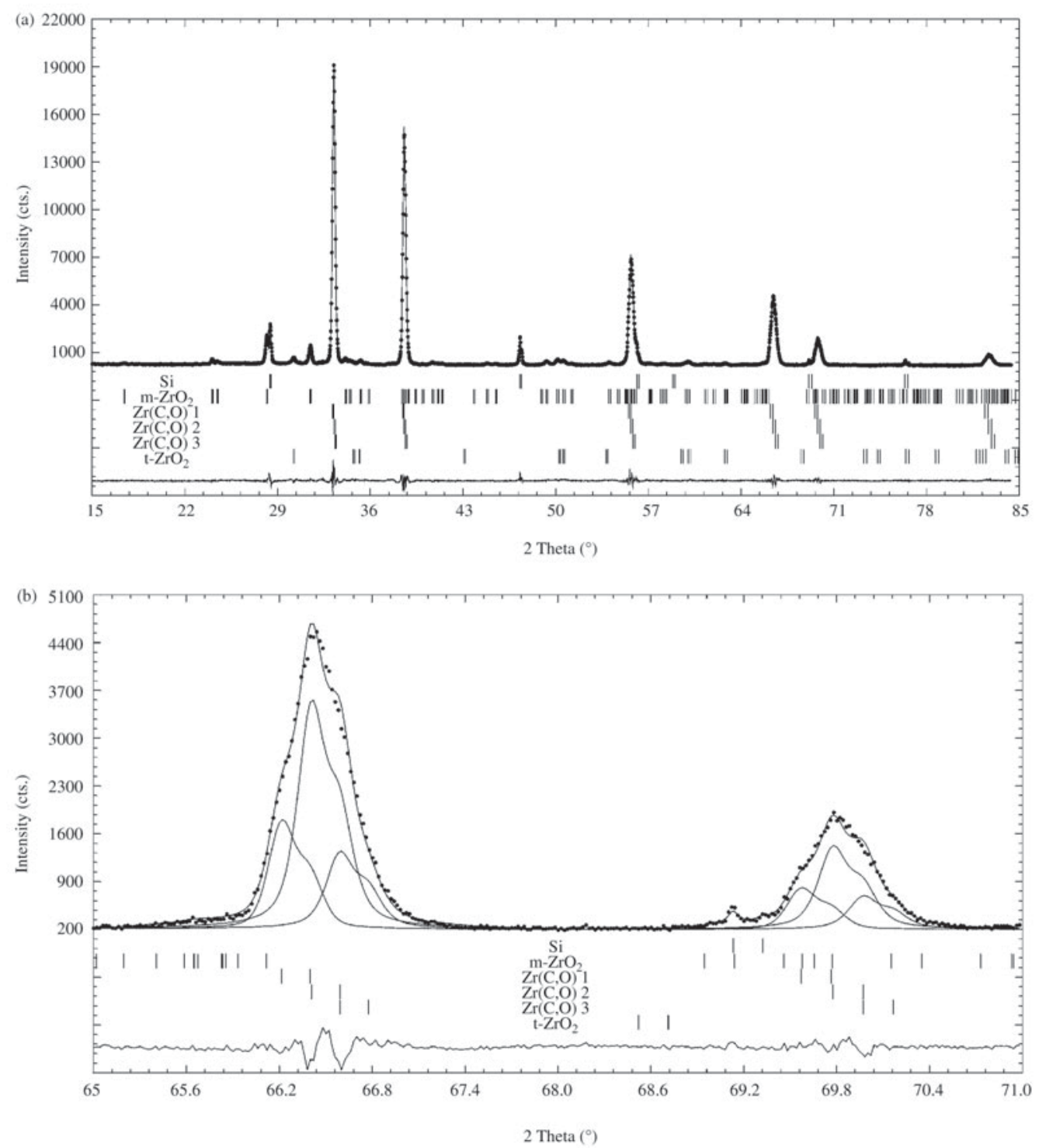

Figure 5. a) Final Rietveld plot for sample B450 treated at $1600{ }^{\circ} \mathrm{C}$. b) Amplified plot of $61^{\circ}-71^{\circ}$ zone 


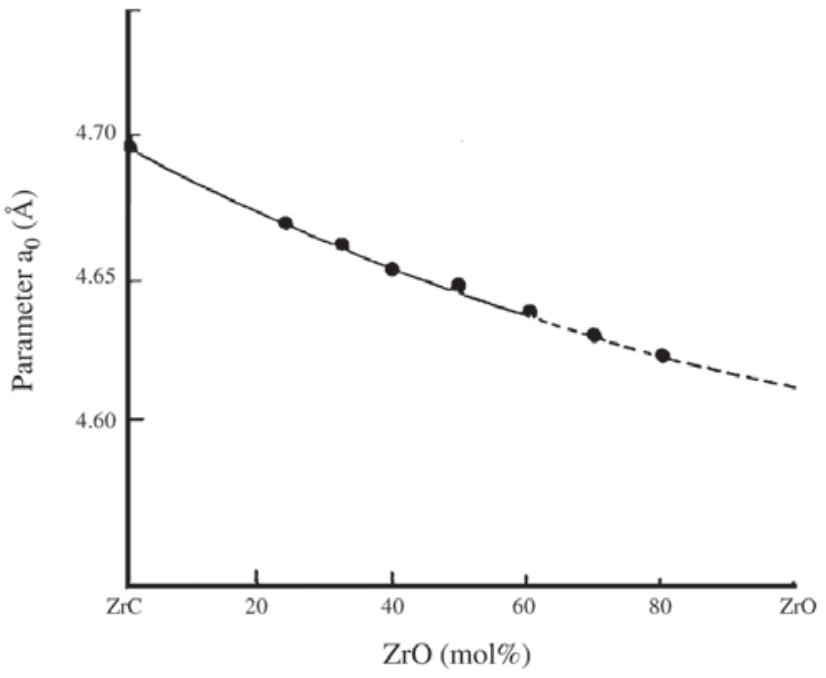

Figure 6. Unit-cell parameter $\mathrm{a}_{\mathrm{o}}$ vs. $\mathrm{Zr}(\mathrm{C}, \mathrm{O})$ composition taken from Kosolapova et al. ${ }^{4}$.
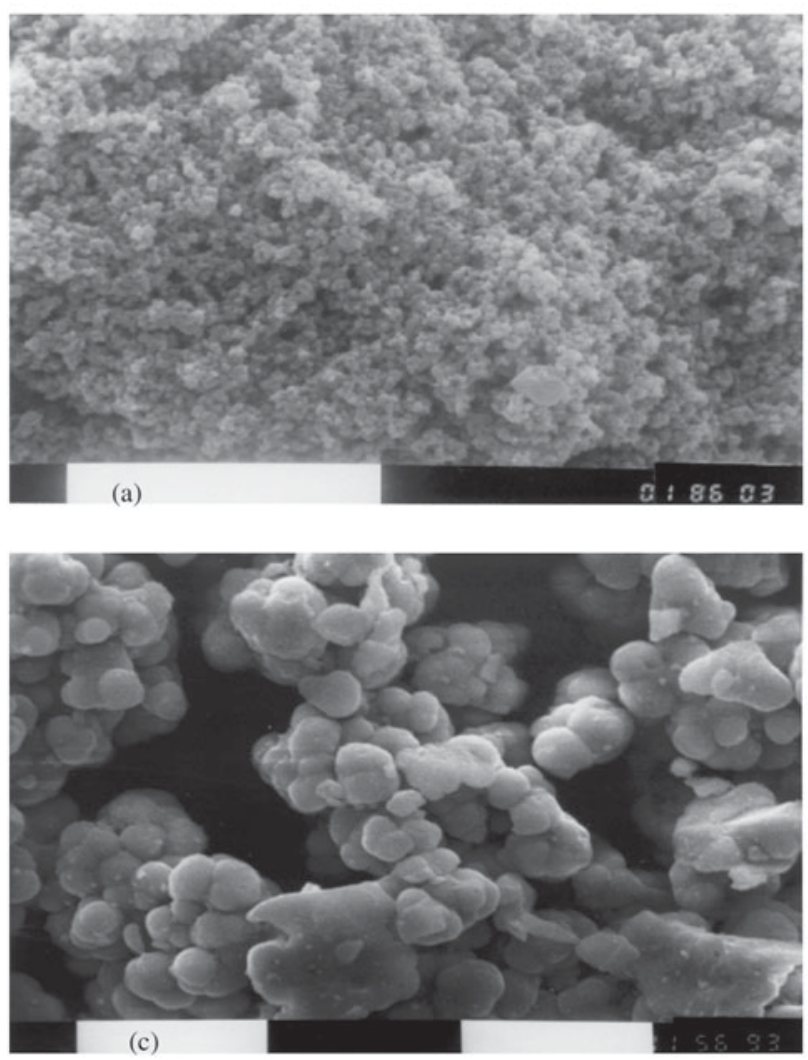

All samples have enough carbon to obtain an oxicarbide as unique phase. Theoretically oxicarbide compositions would be between $\mathrm{ZrC}_{0.45} \mathrm{O}_{0.55}$ for $\mathrm{B} 180$ and $\mathrm{ZrC}$ for $\mathrm{B} 300$.

The zirconium phases obtained were: $\mathrm{Zr}(\mathrm{C}, \mathrm{O})$ phase, monoclinic $\mathrm{ZrO}_{2}$ (badeleyite) and tetragonal $\mathrm{ZrO}_{2}$ in lower proportions. Figure 5 a shows the final Rietveld plot for sample B450 treated at $1600{ }^{\circ} \mathrm{C}$ and Fig. $5 \mathrm{~b}$ is part of the same graphic amplified to show the overlap of $\operatorname{Zr}(\mathrm{C}, \mathrm{O})$ peaks belonging to different phases. In Fig. 5b, individual calculated profiles for all $\mathrm{Zr}(\mathrm{C}, \mathrm{O})$ phases are also shown.

Badeleyite is the principal phase at temperatures lower than $1600^{\circ}$. The amount of this phase decreases with the increase of temperature and carbon content, being the minority phase at higher temperatures. Mean unit-cell parameters refined for badeleyite were: $a=5.151(3) \AA$, $\mathrm{b}=5.210(5) \AA, \mathrm{c}=5.318(5) \AA$ and $\mathrm{b}=99.27(4)^{\circ} \AA$.

Tetragonal zirconia content was between 1 and 3 wt. $\%$ in all samples containing $\mathrm{ZrO}_{2}$ presenting similar behavior to the badeleyite.

$\mathrm{Zr}(\mathrm{C}, \mathrm{O})$ increases with the increase of temperature and carbon content. It is the principal phase at a temperature of $1600^{\circ}$ or higher.
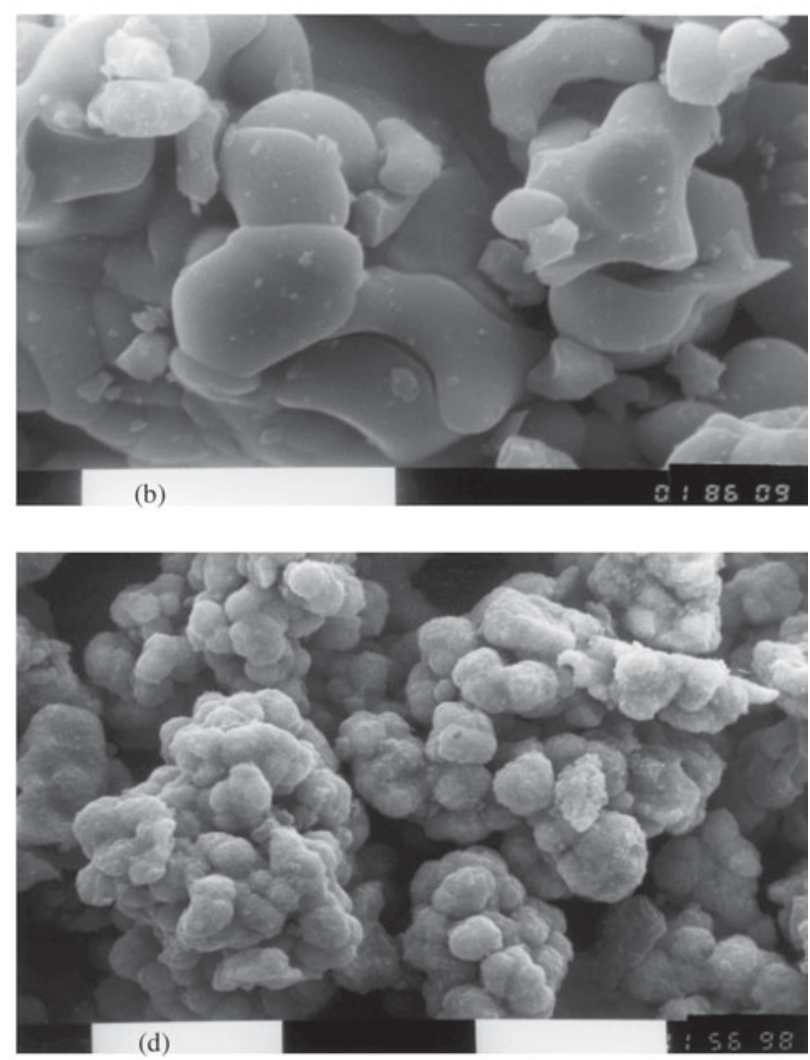

Figure 7. Micrographies (SEM) of reagents and products (scale: white bar $=10 \mu \mathrm{m}$ ). a) Anatase; b) A200 sample treated at $1650{ }^{\circ} \mathrm{C}$; $\mathrm{c}$ ) Badeleyite; d) $\mathrm{B} 300$ sample treated at $1650{ }^{\circ} \mathrm{C}$. 
The obtained values of $\mathrm{a}_{\mathrm{o}}(4.640 \AA-4.683 \AA)$ show that the formed oxicarbides were within the range $\mathrm{ZrC}_{0.46} \mathrm{O}_{0.54}-\mathrm{ZrC}_{0.9} \mathrm{O}_{0.1}$ (between 54 and 10 mol\%.of $\mathrm{ZrO}$ ). The composition range was determined using the calibration curve $\mathrm{a}_{\mathrm{o}}$ vs. $\mathrm{Zr}(\mathrm{C}, \mathrm{O})$ composition (Fig. 6). This curve, from Kosolopova et $\mathrm{al}^{4}{ }^{4}$, was obtained from samples prepared by reaction of pure $\mathrm{Zr}, \mathrm{ZrO}_{2}$ and $\mathrm{ZrC}$.

The Rietveld analysis shows that the wide peaks can be fitted using two or more phases $\mathrm{M}(\mathrm{C}, \mathrm{O})$ indicating that the wide peaks are actually due to overlap of several narrow peaks. In almost all the samples, the use of two phases allowed to have $\mathrm{R}_{\mathrm{Bragg}}$ values near 2.85 for both $\mathrm{M}(\mathrm{C}, \mathrm{O})$. The $\mathrm{R}_{\text {exp }}$ are between 4.63 and 5.97 and the $\mathrm{R}_{\mathrm{wp}}$ are between 9.20 and 15.56. This phenomenon can be observed in other systems where there are phases having changeable compositions and unit-cell parameters associated ${ }^{13-15}$.

The crystal sizes of the $\operatorname{Zr}(\mathrm{C}, \mathrm{O})$ and $\mathrm{Ti}(\mathrm{C}, \mathrm{O})$ were calculated using the width of peaks (200) determined from the fitting results. Both phases presented similar behavior, with crystal size values between $560 \AA$ and $3000 \AA$ without a definite tendency.

Table 6 shows a weight loss increase with the increase of temperature in all samples. The carbon content has influence at $1600{ }^{\circ} \mathrm{C}$ or higher temperatures when the $\operatorname{Zr}(\mathrm{C}, \mathrm{O})$ is the principal phase. High weight loss values obtained principally for sample B180 may be due to $\mathrm{ZrO}_{(\mathrm{g})}$ loss (reaction $\mathrm{C}$ ).

$$
\begin{aligned}
& \mathrm{ZrO}_{2}+\mathrm{C} \rightarrow \mathrm{ZrO}_{(\mathrm{g})}+\mathrm{CO}_{(\mathrm{g})} \\
& \mathrm{ZrO}_{(\mathrm{g})}+2 \mathrm{C} \rightarrow \mathrm{ZrC}+\mathrm{CO}_{(\mathrm{g})}
\end{aligned}
$$

But in samples with high carbon content, the $\mathrm{ZrO}_{(\mathrm{g})}$ loss my be limited by reaction $\mathrm{D}$.

Finally, reagents and reaction products were characterized by scanning electron microscopy (SEM). Morphology variations caused by reactions were observed (Fig. 7).

When comparing the $\mathrm{TiO}_{2}$ reagent with the reaction products an important increase of the particle size is observed, indicating their sintering. This phenomenon can also be observed in low temperature samples. Besides, the $\mathrm{TiO}_{2}$ grain morphology and that of the products are different.

Nevertheless, B samples seem to preserve the morphology and size of the raw material that originates them (the badeleyite).

\section{Conclusions}

1. Carborreduction reactions of $\mathrm{TiO}_{2}$ and $\mathrm{ZrO}_{2}$ are a suitable method to prepare oxycarbides of $\mathrm{TiO}-\mathrm{TiC}$ and $\mathrm{ZrO}-\mathrm{ZrC}$ systems respectively.

2. All oxycarbides obtained belong to MO-MC axes of MO-MC-MN system.

3. The carbon content of oxycarbides increased with reaction temperature.

4. Carboreduction of $\mathrm{TiO}_{2}$ produced $\mathrm{Ti}(\mathrm{C}, \mathrm{O})$ as unique product at temperatures higher than $1450{ }^{\circ} \mathrm{C}$ and carbon/mineral ratios higher than 0.360 . In the other samples some titanium oxides and suboxides were obtained but non remainder $\mathrm{TiO}_{2}$ was detected.

5. Carboreduction of $\mathrm{ZrO} 2$ produced $\mathrm{Zr}(\mathrm{C}, \mathrm{O})$ as unique reaction product.

6. The Rietveld method allowed to characterize titanium and zirconium oxycarbides obtained by carboreduction and also to refine unit cell parameters of minority phases.

7. The observation by SEM permitted to see the $\mathrm{TiO}_{2}$ and $\mathrm{ZrO}_{2}$ different behavior with regard to their morphology modification during these reactions.

\section{References}

1. Neumann, G.; Kieffer, R.; Ettmayer, P. Über das System TiC-TiNTiO, Monatshefte für Chemie, v. 103, p. 1130-1137, 1972.

2. Constant, K.; Kieffer, R.; Ettmayer,P. Über das pseudoternare system ZrO-ZrN-ZrC, Monatshefte fur Chemie, v. 106, p. 823, 1975.

3. Krainer, H.; Konopicky, K. Untersuchungen von sinterhartmetallen. Berg-und Huttenm. Mh. v. 92, p. 166, 1950.

4. Kosolapova, T.Y.; Fedorus, V.B.; Panasyuk, A.D.; Kotzina, G.K. Über das System ZrC-ZrO. Poroschkowaya metall. n.1, p. 109, 1972.

5. Young R.A, The Rietveld Method. IUCr, Oxford University Press, NY, USA, 1993.

6. Rodriguez-Caravajal, Abstracts of the Satellite Meeting on Powder Difraction of XV Congres of the IUCr, Toulouse, France, p.127, 1990.

7. Howard, C.J.; Hill, R.J.; Reichert, B.E. Structures of $\mathrm{ZrO}_{2}$ Polymorphs at Room Temperature by High-Resolution Neutron Powder Diffraction. Acta Crystallographica v. 44, p. 116-120, 1988.

8. Wyckoff, R.W.G. Crystal Structures, Interscience, New York, 1963.

9. Le Page,Y.; Strobel, P. Structural Chemistry of Magnéli Phases $\mathrm{Ti}_{\mathrm{n}} \mathrm{O}_{2 \mathrm{n}-1}(4 \leq \mathrm{n} \leq 9)$. I Cell and Structure Comparisons, Journal of Solid State Chemistry, v. 43, p. 314-319, 1982.

10. Åsbrink S.; Magnéli A. Crystal Structure Studies on Trititanium Pentoxide, $\mathrm{Ti}_{3} \mathrm{O}_{5}$, Acta Crystallographica, v. 12, p. 575-581, 1959.

11. Hong, S.H.; Åsbrink, S. The structure of $\gamma-\mathrm{Ti}_{3} \mathrm{O}_{5}$, Acta Crystallographica, v. B38, p. 2570-2576, 1982.

12. Afir, A.; Achour, M.; Saoula, N. X - ray Diffraction study of Ti-O$\mathrm{C}$ system at high temperature and in continuous vacumm, Journal of Alloys and Compounds, v. 288, p. 124-140, 1999.

13. Mazzoni, A.D.; Aglietti, E.F.; Pereira, E. Carbonitriding of clay: Relation between the weight loss and crystalline phases during reaction, Journal of American Ceramic Society, v. 76, n. 9, p. 23372340, 1993.

14. Mazzoni, A.D. Conconi, M.S.; Aglietti, E.F., Synthesis of Zr-Si$\mathrm{O}-\mathrm{N}$ Phases by Carbonitriding Reaction, Characterization of Crystalline Phases Using the Rietveld Method, Materials Research, v. 4, n. 2, p. 107-111, 2001.

15. Mazzoni, A.D.; Conconi, M.S. Carbonitruración de $\mathrm{ZrO}_{2}$. Caracterización de productos mediante el método de Rietveld, Anales del V Congreso de Cerámica del Mercosur, Buenos Aires, Argentina, p. 32, 2000. 